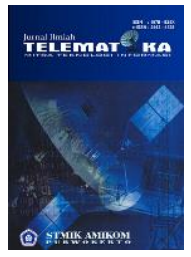

Terbit online pada laman web jurnal

http:/lejournal.amikompurwokerto.ac.id/index.php/telematika/

\title{
Peningkatan Kualitas Citra Hasil Enhancement Dengan Metode Peningkatan Rata - Rata Dan Simpangan Baku Berbasis Statistik Representasi Visual
}

\author{
Faruk Alfiyan
}

Program Studi Teknik Informatika

Sekolah Tinggi Ilmu Komputer (STIKOM) PGRI Banyuwangi

Email : farukalfiyan@gmail.com

\section{N F O A R T I K E L}

Sejarah artikel:

Menerima 1 Juli 2019

Revisi 20 Juli 2019

Diterima 29 Agustus 2019

Online Agustus 2019

\section{Kata kunci:}

Citra

Rata-rata

Simpangan Baku

Statistik

\section{Keywords:}

Image

Average

Standard Deviation

Statistics

\section{Korespondensi:}

Telepon: 082335962954

E-mail: farukalfiyan@

stikombanyuwangi.ac.id

\begin{abstract}
ABSTRAK
Penurunan kualitas sebuah citra seringkali terjadi akibat adanya proses perbaikan yang dilakukan pada citra tersebut. Penurunan kualitas citra umumnya ditandai dengan hilangnya kontras pada beberapa lokal citra dan juga hilangnya detail dalam bagian tertentu citra. Dampak dari hal ini tentu akan sangat besar pada citra, karena informasi atau data yang terkandung dalam citra akan bias dan jauh dari relevansinya. Untuk meminimalisir penurunan kualitas citra yang disebabkan karena proses enhancement citra, maka harus dilakukan langkahlangkah yang dapat mengembalikan informasi yang ada dalam citra asal ke dalam citra hasil enhancement tersebut. Dengan menggabungkan kembali citra asal dan citra hasil enhancement, informasi yang hilang pada citra akan dapat dikembalikan sebagaimana mestinya. Namun proses penggabungan citra tersebut harus didahului dengan sebuah proses yang dapat meningkatkan ratarata nilai dan rata-rata dari simpangan baku citra hasil enhancement. Jika kedua proses tersebut dilakukan dengan benar, maka informasi yang didapat dari penggabungan kedua citra akan memberikan hasil yang maksimal. Dari uji coba terhadap lima ratus sample citra yang dikelompokkan dalam tiga kategori, yaitu citra dengan tingkat brightness kurang, citra dengan tingkat kontras kurang, dan citra dengan tingkat brightness dan kontras kurang, terdapat tujuh puluh empat sample citra yang belum dapat diperbaiki. Sedangkan pada sample citra uji coba yang lain, dapat diperbaiki kekurangannya. Artinya keberhasilan yang telah dicapai sebesar delapan puluh lima persen.
\end{abstract}

\footnotetext{
ABSTRACT

Decreasing the quality of an image often occurs due to the process of improvement made on the image. The decrease in image quality is generally characterized by loss of contrast in some local images and also loss of detail in certain parts of the image. The impact of this will certainly be very large in the image because the information or data contained in the image will be biased and far from its relevance.To minimize the decline in image quality caused by the image enhancement process, steps must be taken to restore the information contained in the original image into the enhancement image. By re-combining the original image and the enhancement image, the information lost in the image will be restored accordingly. But the process of combining these images must be preceded by a process that can increase the average value and average of the standard deviation of the image results of enhancement. If the two processes are carried out correctly, the information obtained from the merging of the two images will give maximum results. From the trial of five hundred image samples grouped in three categories, namely images with less brightness, images with less contrast levels, and images with less brightness and contrast, there are seventy-four image samples that cannot be repaired. Whereas in other trial sample images, the deficiencies can be corrected. This means that the success achieved is eighty-five percent.
} 


\section{PENDAHULUAN}

Tujuan dari dilakukannya sebuah enhancement atau perbaikan kualitas citra adalah untuk menjadikan suatu citra memiliki kualitas yang lebih baik dari citra asalnya. Proses enhancement juga dapat dilakukan untuk meningkatkan persepsi dan interpretasi dari sebuah informasi yang terdapat pada sebuah citra, dan juga untuk menghasilkan sebuah input yang lebih maksimal pada proses citra digital berikutnya.

Berbagai macam metode enhancement citra digital dengan domain spatial telah ditemukan. Teknik yang digunakan juga bervariasi. Ada yang menggunakan teknik penghitungan neighborhood, penghitungan kontras pada beberapa lokal citra, atau penghitungan pada nilai piksel citranya. Secara garis besar beberapa metode enhancement tersebut mampu menghasilkan perbaikan, baik pada sisi informasi atau persepsi pada indra penglihatan manusia. Namun di sisi lain proses enhancement yang dilakukan justru malah menurunkan kualitas citra itu sendiri. Metode Multi Scale Retinex, Gamma Correction, atau metode Gradient Domain, adalah contoh beberapa metode enhancement citra yang ada saat ini. Di satu sisi metode-metode tersebut berhasil melakukan enhancement, namun di sisi lain justru malah mengurangi detail dan kualitas kontras pada beberapa lokal citra. (Jobson, Rahman \& Woodell, 2017).

Untuk menutup kekurangan dari beberapa metode tersebut, Chen menggunakan teknik fusi, dimana nilai bobot yang digunakan diperoleh dengan cara sigmoidal yang didasarkan pada penghitungan kontras pada beberap lokal citra. Metode yang ditawarkan Chen ini mampu memperbaiki kekurangan citra hasil enhancement. Teknik yang digunakan adalah dengan mengambil kembali kontras yang hilang pada beberapa lokal citra hasil enhancement dari citra asalnya. Namun demikian metode yang digunakan Chen ini tingkat keberhasilannya bergantung dari seberapa tinggi kualitas citra asalnya. Jika citra asalnya memiliki kualitas yang rendah, maka rendah pula kualitas citra hasil enhacement. Sebaliknya jika citra asalnya memiliki kualitas yang tinggi, maka tinggi pula kualitas citra hasil enhacement. (Chen, Sun, \& Xia, 2017).

Sebagaimana yang telah dilakukan Chen, Arifin juga telah mencoba melakukan perbaikan kembali kualitas citra hasil enhancement. Teknik yang digunakan adalah dengan mengevaluasi tampilan histogram dari citra hasil enhancement. Evaluasi dimulai dengan menentukan rentang nilai grayscale pada citra, jumlah pixel pada rentang grayscale yang telah ditenttukan, dan jumlah seluruh pixel citra. Jika hasil pembagian dari jumlah pixel pada rentang grayscale dan jumlah seluruh pixel citra hasilnya berada diantara rentang setengah sampai dengan tiga persen, maka pixel pada rentang grayscale tersebut digabungkan dengan pixel pada rentang berikutnya. Agar dapat dikategorikan kedalam citra ideal sebagaimana kriteria statistik dan visual representasi, citra hasil dari evaluasi ini ditingkatkan standar deviasinya. Teknik yang digunakan Arifin ini mampu menutup kekurangan kontras lokal dari citra hasil enhancement. Akan tetapi teknik ini tidak dapat berfungsi dengan maksimal untuk citra yang kualitas kontras dan brigthnessnya rendah. (Arifin \& Arieshanti, 2017).

Dalam salah satu penelitan yang dilakukan oleh Jobson terungkap bahwa representasi suatu citra secara visual ternyata memiliki keterkaitan dengan nilai statistik dari $\mu$ dan $\sigma$. Nilai brihtness di representasikan dengan nilai $\mu$ sedang nilai kontras direpresantasikan dengan nilai $\sigma$. Sebuah citra ideal memiliki rentang nilai $\mu$ antara seratus sampai dengan dua ratus dan nilai $\sigma$ antara empat puluh sampai 
dengan delapan puluh. Adapun citra ideal yang dinormalisasi memiliki rentang nilai $\mu 0.3921$ sampai dengan 0.7843 dan rentang nilai $\sigma 0.1568$ sampai dengan 0.3137. (Jobson, Rahman \& Woodell, 2018).

Ruang lingkup dan batasan masalah dari penelitian ini adalah : sample citra yang digunakan adalah citra grayscale yang secara statistik dan visual representasinya berada diluar kategori citra ideal, serta metode enhancement yang digunakan adalah Gamma Correction.

Adapun tujuan dari penelitian ini adalah untuk meningkatkan kualitas kontras dan detail citra yang menurun akibat proses enhancement sehingga output yang dihasilkan dapat menjadi input yang lebih baik dalam proses selanjutnya.

\section{METODE PENELITIAN}

Langkah-langkah yang dilakukan untuk melakukan peningkatan kualitas citra hasil enhancement ditunjukkan dalam blok diagram metode berikut :

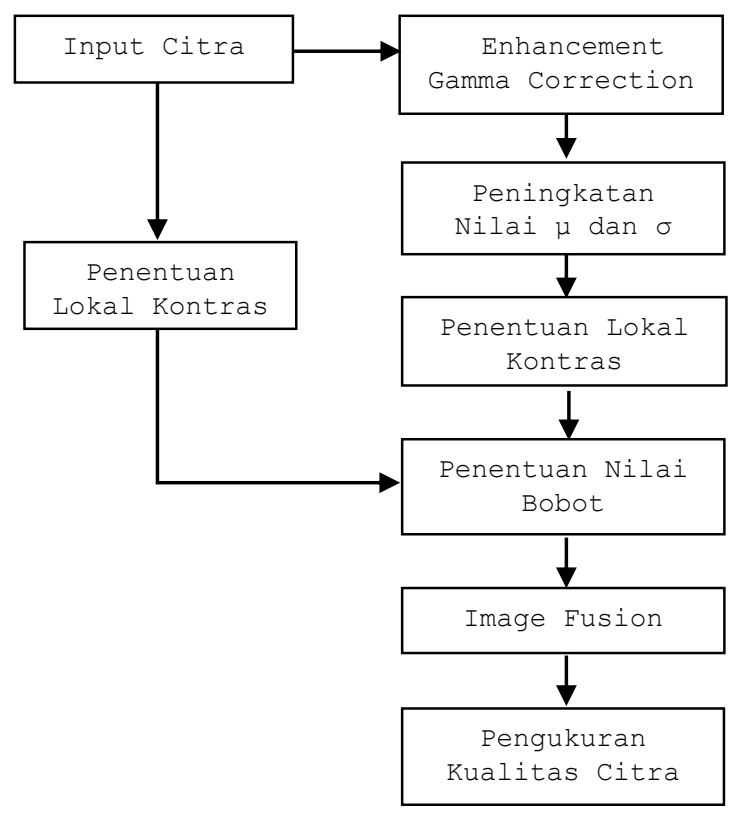

Gambar 1. Blok diagram metode

\section{Input Citra}

Penentuan input citra berfungsi untuk menentukan sample yang akan digunakan sebagai citra input dalam uji coba. Penentuan dan penyeleksian sample citra input dilakukan dengan melakukan penghitungan nilai $\mu$ dan nilai $\sigma$ citra. Dari hasil penghitungan ini akan dapat ditentukan apakah citra tersebut termasuk kategori citra ideal atau tidak. Sample citra yang dipilih hanyalah citra yang kategorinya termasuk citra yang tidak ideal secara statistik dan secara visual representatif.

Secara statistik tingkat brightness ditentukan oleh nilai $\mu$ citra, sedangkan tingkat kontras ditentukan oleh nilai $\sigma$ citra. Penetapan region parameter citra dilakukan dengan membagi citra dalam beberapa blok, dimana setiap blok mempunyai ukuran 50 x 50 pixel. Penghitungan nilai $\mu$ dan $\sigma$ citra dilakukan pada tiap blok tersebut. Persamaan yang digunakan untuk menghitung nilai $\mu$ blok citra adalah : 


$$
\mu_{f}(i, j)=\frac{1}{(2 P+1)(2 Q+1)} \sum_{m=i-P}^{i+P} \sum_{n=j-Q}^{j+Q} f(m, n)
$$

Sedangkan penghitungan nilai $\sigma$ blok citra dengan menggunakan persamaan berikut:

$$
\sigma_{f}(i, j)=\frac{1}{(2 P+1)(2 Q+1)} \sum_{m=i-P}^{i+P} \sum_{n=j-Q}^{j+Q}\left[f(m, n)-I_{j}(i, j)^{2}\right.
$$

$(2 \mathrm{P}+1)(2 \mathrm{Q}+1)$ adalah lebar sub citra yang di analisa (Kaiqi, Zhenyang, Qiao, 2017).

\section{Enhancement Gamma Correction}

Metode atau teknik yang digunakan untuk enhancement citra input adalah Gammma Correction. Teknik ini dipilih karena Gamma Correction termasuk dari beberapa metode enhancement yang mampu meningkatkan nilai brightness, walaupum di sisi lain teknik enhancement dalam Gamma correction justru membuat kualitas kontras citra menurun. Hasil enhancement Gamma Correction inilah yang akan diperbaiki dengan metode penelitian ini.

Enhancement Gamma Correction pada prinsipnya melakukan perbaikan nilai gamma yang mempengaruhi tingkat brightness dan kontras citra. Persamaan yang digunakan adalah :

$$
s r=c r^{r}
$$

$\mathrm{s}=$ citra hasil, $\mathrm{cr}=$ konstanta positif, dan $\gamma$ adalah faktor koreksi gamma dimana kisaran nilai $0<$ $\gamma<1$. Jika $\gamma=1$ maka hasil transformasinya sama dengan citra aslinya. Tingkat brightness ditentukan oleh besar kecilnya faktor koreksi nilai $\gamma$. Semakin kecil nilainya maka semakin tinggi brightnessnya. Semakin besar nilainya semakin rendah brightnessnya. (Gonzalez \& Woods, 2016)

\section{Peningkatan Nilai $\mu$ dan $\sigma$}

Tujuan dilakukannya peningkatan nilai $\mu$ dan $\sigma$ adalah agar nilai $\mu$ dan $\sigma$ citra masuk dalam kategori citra ideal sesuai kriteria Jobson dalam statistik representasi visual. Teknik peningkatan nilai $\mu$ dilakukan dengan melakukan penjumlahan antara nilai pixel dengan selisih pixel tersebut dengan neighborhoodnya. Persamaan yang digunakan adalah :

$$
g(x, y)=\frac{1}{9} \sum_{i=x-1}^{x+1} \sum_{j=y-1}^{y+1}(|f(x, y)+f(i, j)|)
$$

$\mathrm{g}(\mathrm{x}, \mathrm{y})=$ nilai pixel hasil, $\mathrm{f}(\mathrm{x}, \mathrm{y})=$ nilai pixel asli, dan $\mathrm{f}(\mathrm{i}, \mathrm{j})=$ nilai selisih pixel dengan pixel neighborhoodnya, dimana nilai selisih pixel dihitung dengan mask $3 \times 3$.

Adapun untuk meningkatkan nilai $\sigma$ digunakan unsharp masking. Teknik unsharp masking terbagi dalam tiga tahap. Pertama, membuat citra blur dari citra asli. Kedua, membuat mask dari hasil pengurangan citra asli dengan citra blur. Ketiga, menggabungkan citra asli dengan mask. Persamaan yang digunakan adalah :

$$
g_{\text {mask }}\left(x, y=f(x, y)-f^{1}(x, y)\right.
$$




$$
g\left(x, y=f(x, y)+k * g_{\text {mask }}(x, y)\right.
$$

$\mathrm{f} 1(\mathrm{x}, \mathrm{y})=$ citra blur dan $\mathrm{k}=$ bobot. (Gonzalez \& Woods, 2016)

\section{Penentuan Lokal Kontras}

Penentuan lokal kontras dilakukan tidak hanya dilakukan pada citra asli saja, namun juga dilakukan pada hasil enhancement citra yang telah melalui proses peningkatan $\mu$ dan $\sigma$. Tahap ini memiliki peran yang sangat penting untuk peningkatan kualitas citra, karena melalui proses ini dapat diketahui pada lokal yang mana kontras citra perlu diperbaiki. Lokal kontras ini pula yang dijadikan acuan seberapa besar nilai bobot kedua citra.

Penentuan lokal kontras adalah teknik untuk mengukur kualitas citra yang didasarkan pada selisih intensitas pada kontras yang tinggi dan kontras yang rendah. (Chen et al., 2017). Persamaan yang digunakan adalah :

$$
C_{i}(x, y)=\max \left(N_{i}(x, y)\right)-\min \left(N_{i}(x, y)\right)
$$

\section{Penentuan Nilai Bobot}

Penentuan nilai bobot yang tepat mutlak diperlukan untuk mendapatkan citra hasil dengan kualitas tinggi. Penghitungan nilai bobot diawali dengan mencari selisih lokal kontras dari kedua citra dengan persamaan :

$$
D(x, y)=C_{2}(x, y)-C_{1}(x, y)
$$

Adapun nilai bobot diperoleh dengan persamaan :

$$
W=\frac{1}{1+e^{-a(\widehat{D}-b)}}
$$

dimana $\widehat{D}=D-\frac{\min (D)}{\max (D)-\min (D)}$ dan $\mathrm{b}=-\frac{\min (D)}{\max (D)-\min (D)} \quad$ (Han, Tang, Gao, \& Hu, 2018).

\section{Image Fusion}

Image fusion berfungsi untuk menggabungkan informasi dan detail citra yang terdapat pada beberapa citra kedalam sebuah citra. Tujuan image fusion adalah untuk memperoleh informasi dan detail citra yang lebih baik dibandingkan dengan citra aslinya (Raskar, Ilie, \& Yu, 2017). Image fusion dimulai dengan penentuan bobot setiap citra. Bobot inilah yang dijadikan dasar penggabungan citra. (Gonzalez \& Woods, 2016). Persamaan yang digunakan adalah :

$$
R=\widehat{W} \cdot I_{2}+(1-\widehat{W}) I_{1}
$$

\section{Pengukuran Kualitas Citra Hasil}

Suatu proses yang dilakukan dalam sebuah citra dapat mengakibatkan terjadinya kehilangan informasi pada citra hasil. Oleh karena itu dibutuhkan suatu kriteria untuk mengukur kebenaran hasil proses tersebut. kriteria pengukuran inilah yang disebut dengan Fidelity Criteria (Mevik, 2017). Dalam penelitian ini Fidelity Criteria yang digunakan adalah sebagai berikut: 
a. MSE (Mean Square Error), adalah salah satu teknik yang digunakan untuk mengukur kuantitas perbedaan antara perkiraan dan nilai kebenaran kuantitas yang diperkirakan, atau juga dapat didefinisikan sebagai sigma dari jumlah error antara citra hasil dan citra asli. Untuk mendapatkan nilai MSE digunakan persamaan berikut :

$$
M S E=\frac{1}{M N} \sum_{y=1}^{M} \sum_{x=1}^{N}\left[I(x, y)-I^{\prime}(x, y)\right]^{2}
$$

dimana I(x,y) adalah nilai piksel pada citra asli, I1(x,y) adalah nilai piksel pada citra hasil, sedangkan $\mathrm{M}$ dan $\mathrm{N}$ adalah dimensi citra. Nilai MSE yang kecil pada citra hasil menandakan citra tersebut lebih baik dari citra hasil yang memiliki nilai MSE lebih besar

b. PSNR (Peak Signal to Noise Ratio), adalah salah satu tehnik dalam mengukur kualitas rekonstruksi citra tanpa kehilangan fitur aslinya. Untuk mendapatkan nilai PSNR digunakan persamaan berikut :

$$
P S N R=20 \times \log _{10}\left(\frac{b}{\sqrt{M S E}}\right)
$$

dimana nilai b merupakan nilai maksimum dari piksel citra yang digunakan. Nilai PSNR yang besar pada citra hasil menandakan citra tersebut lebih baik dari citra hasil yang memiliki nilai PSNR lebih kecil

c. SNR (Signal to Noise Ratio), adalah rasio dari daya sinyal dengan daya noise yang merusak sinyal. Untuk mendapatkan nilai SNR digunakan persamaan

$$
S N R=10 \log _{10}\left(\frac{\sum_{x, y} f(x, y)^{2}}{\left.\sum_{x, y} f(x, y)-h(x, y)\right)^{2}}\right)
$$

Nilai SNR yang besar pada citra hasil menandakan citra tersebut lebih baik dari citra hasil yang memiliki nilai SNR lebih kecil (Ghrare, 2018).

\section{HASIL DAN PEMBAHASAN}

Hasil dan pembahasan dari blok diagram metode peneltian adalah sebagai berikut :

\section{Input Citra}

Input citra yang digunakan adalah citra yang nilai $\mu$ dan $\sigma$ nya kurang dari kategori citra ideal yang didasarkan pada kaidah statistik dan representasi visual. Input citra diklasifikasikan dalam tiga kelompok. Pertama, input citra yang memiliki nilai $\mu$ dan $\sigma$ kurang. Kedua, citra dengan nilai $\mu$ cukup, dan nilai $\sigma$ kurang. Ketiga, citra yang memiliki nilai $\mu$ kurang dan memiliki nilai $\sigma$ cukup.

Pengklasifikasian input citra dilakukan dengan menggunakan persamaan 1 dan 2 . Dalam setiap klasifikasi diwakili oleh dua buah citra yang ditunjukkan dalam tabel 1 : 
Tabel 1. Klasifikasi input citra

\begin{tabular}{|c|c|c|c|c|}
\hline No & Input citra & Klasifikasi & $\boldsymbol{\mu}$ & $\sigma$ \\
\hline 1 & & \multirow{2}{*}{$\begin{array}{l}\text { Nilai } \mu \text { dan } \sigma \\
\text { kurang (nilai } \mu \\
\text { tidak mencapai } \\
0.3921 \text {, nilai } \sigma \\
\text { tidak mencapai } \\
0.1568 \text { ) }\end{array}$} & 0.3306 & 0.1526 \\
\hline 2 & & & 0.3325 & 0.1423 \\
\hline 3 & & \multirow{2}{*}{$\begin{array}{l}\text { Nilai } \mu \text { cukup } \\
\text { (berada di } \\
\text { rentang } 0.3921 \\
\text { s/d } 0.7843 \text { ), } \\
\text { nilai } \sigma \text { kurang } \\
\text { (tidak mencapai } \\
0.1568\end{array}$} & 0.4072 & 0.1514 \\
\hline 4 & & & 0.3936 & 0.1415 \\
\hline 5 & & \multirow{2}{*}{$\begin{array}{l}\text { Nilai } \mu \text { kurang } \\
\text { (tidak mencapai } \\
0.3921 \text { ), nilai } \sigma \\
\text { cukup (berada } \\
\text { di rentang } \\
\text { 0.1568 s/d } \\
0.3137 \text { ) }\end{array}$} & 0.3844 & 0.1676 \\
\hline 6 & & & 0.3226 & 0.1999 \\
\hline
\end{tabular}

Adapun input citra lainnya disajikan dalam supplementary file. Dalam supplementary file tersebut juga telah dimasukkan citra dengan object yang berbeda, seperti citra dengan object manusia, binatang dan berbagai macam object lainnya.

\section{Enhancement Gamma Correction}

Enam buah citra input yang ditunjukkan dalam tabel 1, semuanya tidak termasuk dalam kategori citra ideal yang didasarkan pada kaidah statisk dan representasi visual. Hal inilah yang menjadi dasar perlunya dilakukan enhancement pada enam citra input tersebut. Proses enhancement Gamma Correction menggunakan persamaan 3. Hasilnya ditunjukkan dalam tabel berikut :

Tabel 2. Enhancement citra

\begin{tabular}{ccccc}
\hline \multirow{2}{*}{ Input } & \multicolumn{2}{c}{ Nilai $\boldsymbol{\mu}$ dan $\boldsymbol{\sigma}$} & \multicolumn{2}{c}{ Hasil enhancement } \\
\cline { 2 - 5 } & $\mu$ & $\sigma$ & $\mu$ & $\sigma$ \\
\hline Citra 1 & 0.3306 & 0.1526 & 0.5561 & 0.1253 \\
\hline Citra 2 & 0.3325 & 0.1423 & 0.5828 & 0.1270 \\
\hline Citra 3 & 0.4072 & 0.1514 & 0.6362 & 0.1228 \\
\hline Citra 4 & 0.3936 & 0.1415 & 0.6159 & 0.1386 \\
\hline Citra 5 & 0.3844 & 0.1676 & 0.5781 & 0.1396 \\
\hline Citra 6 & 0.3226 & 0.1999 & 0.5685 & 0.1541 \\
\hline
\end{tabular}

Dari data tabel 2 dapat diketahui bahwa nilai $\mu$ pada citra hasil enhancement meningkat, namun nilai $\sigma$ justru menurun. Hal inilah yang menyebabkan kontras citra mengalami penurunan kualitas. 


\section{Peningkatan Nilai $\mu$ dan $\sigma$}

Peningkatan nilai $\mu$ dan $\sigma$ bertujuan untuk mengupayakan nilai keduanya berada dalam kategori nilai ideal citra. Untuk peningkatan nilai $\mu$ digunakan persamaan 4. Sedangkan peningkatan nilai $\sigma$ digunakan persamaan 5 dan 6 . Hasil dari peningkatan kedua nilai tersebut ditunjukkan tabel berikut :

Tabel 3. Peningkatan $\mu$ dan $\sigma$

\begin{tabular}{ccccc}
\hline \multirow{2}{*}{ Enhancement } & \multicolumn{2}{c}{ Nilai $\boldsymbol{\mu}$ dan $\boldsymbol{c}$} & \multicolumn{2}{c}{ Peningkatan nilai } \\
\cline { 2 - 5 } & $\mu$ & $\sigma$ & $\mu$ & $\sigma$ \\
\hline Citra 1 & 0.5561 & 0.1253 & 0.5916 & 0.2283 \\
\hline Citra 2 & 0.5828 & 0.1270 & 0.6302 & 0.2757 \\
\hline Citra 3 & 0.6362 & 0.1228 & 0.6838 & 0.2130 \\
\hline Citra 4 & 0.6159 & 0.1386 & 0.6593 & 0.1952 \\
\hline Citra 5 & 0.5781 & 0.1396 & 0.6198 & 0.2377 \\
\hline Citra 6 & 0.5685 & 0.1541 & 0.6026 & 0.2222 \\
\hline
\end{tabular}

Dari data tabel 3 dapat diketahui bahwa semua citra hasil enhancement mengalami peningkatan nilai $\mu$ dan $\sigma$. Nilai inilah yang dijadikan dasar perhitungan nilai lokal kontrasnya.

\section{Penentuan Lokal Kontras}

Penentuan lokal kontras dilakukan dengan persamaan 7. Lokal kontras inilah yang dijadikan dasar dari penentuan bobot citra input dan citra enhancement yang sudah ditingkatkan nilai $\mu$ dan $\sigma$ nya. Hasil penentuan lokal kontras ditunjukkan tabel berikut :

Tabel 3. Lokal kontras

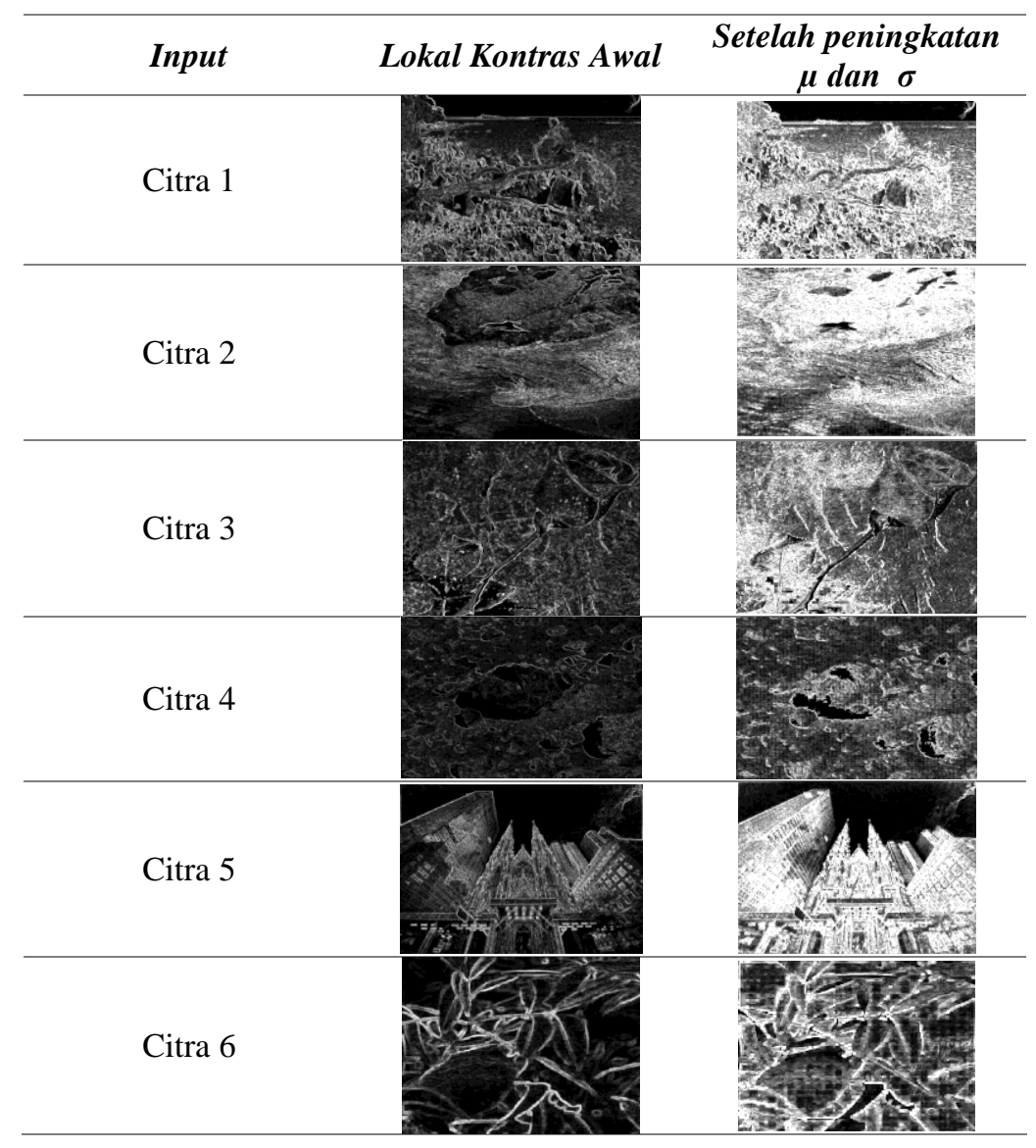




\section{Image fusion}

Tujuan dilakukannya image fusion pada citra input dan citra hasil peningkatan $\mu$ dan $\sigma$ adalah untuk menutup celah yang dapat menyebabkan kualitas citra menurun. Selain itu dengan image fusion data dan informasi yang terkandung dalam citra hasil akan jauh lebih baik dari pada citra asalnya. Proses image fusion dilakukan dengan menggunakan persamaan 10. Hasil image fusion baik secara statistik maupun secara representasi visual ditunjukkan tabel berikut :

Tabel 4. Citra hasil

\begin{tabular}{|c|c|c|c|}
\hline \multirow{2}{*}{ Output } & \multicolumn{2}{|c|}{ Statistik } & \multirow{2}{*}{$\begin{array}{c}\text { Representasi } \\
\text { Visual }\end{array}$} \\
\hline & $\boldsymbol{\mu}$ & $\sigma$ & \\
\hline Citra 1 & 0.3961 & 0.1773 & \\
\hline Citra 2 & 0.3926 & 0.1701 & \\
\hline Citra 3 & 0.4889 & 0.1713 & \\
\hline Citra 4 & 0.4985 & 0.1659 & \\
\hline Citra 5 & 0.4354 & 0.1781 & \\
\hline Citra 6 & 0.4139 & 0.2097 & \\
\hline
\end{tabular}

Data dalam tabel 4 menunjukkan bahwa setelah dilakukan image fusion antara citra input dan citra hasil enhancement yang telah ditingkatkan nilai $\mu$ dan $\sigma$, maka diperoleh output citra yang memiliki nilai $\mu$ dan $\sigma$ citra ideal baik secara statistik maupun dalam representasi visual.

\section{Pengukuran Kualitas Citra Hasil}

Tahap akhir dari rangkaian blok diagram penelitian adalah melakukan pengukuran citra hasil serta membandingkannya dengan beberapa metode sejenis yang telah ada sebelumnya. Pengukuran citra hasil ini bertujuan untuk mengetahui seberapa tinggi kualitas citra yang dihasilkan. Pengukuran kualitas citra hasil dilakukan dengan Fidelity Criteria. Pengukuran MSE menggunakan persamaan 11, PSNR dengan persamaan 12, dan SNR dengan persamaan 13. Adapun penelitian sebelumnya yang digunakan 
sebagai pembanding adalah penelitian Arifin dan Chen. Hasil fidelity criteria dari ketiga penelitian tersebut ditunjukkan tabel berikut :

Tabel 5. Data fidelity criteria

\begin{tabular}{rlrrr}
\hline \multirow{2}{*}{ Input } & $\begin{array}{l}\text { Fidelity } \\
\text { criteria }\end{array}$ & $\begin{array}{c}\text { Metode } \\
\text { Arifin }\end{array}$ & $\begin{array}{c}\text { Metode } \\
\text { Chen }\end{array}$ & $\begin{array}{c}\text { Hasil } \\
\text { Penelitian }\end{array}$ \\
\hline \multirow{3}{*}{ Citra 1} & MSE & 1274.29 & 169.19 & 602.58 \\
\cline { 2 - 5 } & PSNR & 17.10 & 15.84 & 20.44 \\
\cline { 2 - 5 } Citra 2 & SNR & 10.10 & 8.83 & 13.41 \\
\cline { 2 - 5 } & MSE & 1284.50 & 1581.00 & 469.81 \\
\cline { 2 - 5 } & PSNR & 17.04 & 16.14 & 21.41 \\
\hline \multirow{3}{*}{ Citra 3 } & SNR & 9.31 & 8.41 & 13.68 \\
\cline { 2 - 5 } & PSNR & 739.02 & 1449.70 & 679.69 \\
\cline { 2 - 5 } Citra 4 & SNR & 19.44 & 16.52 & 19.81 \\
\cline { 2 - 5 } & MSE & 13.38 & 10.45 & 13.74 \\
\cline { 2 - 5 } & PSNR & 17.40 & 1551.60 & 985.21 \\
\hline \multirow{3}{*}{ SNR } & 11.15 & 16.22 & 18.20 \\
\cline { 2 - 5 } & MSE & 570.91 & 1016.50 & 479.46 \\
\hline \multirow{3}{*}{ Citra 6 } & PSNR & 20.57 & 18.06 & 21.32 \\
\cline { 2 - 5 } & SNR & 14.79 & 12.29 & 15.55 \\
\cline { 2 - 5 } & MSE & 1003.70 & 1543.50 & 806.03 \\
\cline { 2 - 5 } & SNR & 18.11 & 16.25 & 19.07 \\
\hline
\end{tabular}

Data pengukuran kualitas citra hasil dari ketiga metode yang dibandingkan menunjukkan bahwa nilai MSE terkecil terdapat pada citra hasil penelitian. Nilai SNR dan PSNR terbesar juga terdapat pada citra hasil penelitian. Hal ini menunjukkan bahwa kualitas citra hasil penelitian lebih baik dari hasil penelitian sebelumnya.

\section{KESIMPULAN}

Dari seluruh proses penelitian dapat disimpulkan bahwa metode yang digunakan dalam penelitian ini berhasil meningkatkan kualitas citra enhancement sesuai standar statistik dan representasi visual dimana rentang nilai $\mu$ berada diantara 0.3921 sampai dengan 0.7843 dan rentang nilai $\sigma$ berada diantara 0.1568 sampai dengan 0.3137 .

\section{DAFTAR PUSTAKA}

Arifin, A. Z., \& Arieshanti, I. (2017). Perbaikan Kualitas Citra Dengan Metode Fusi Berbasis Pada Statistik Representasi Visual. 1-7. Surabaya.

Chen, Q., Xu, X., Sun, Q., \& Xia, D. (2017). A solution to the deficiencies of image enhancement. Signal Processing, 90(1), 44-56. https://doi.org/10.1016/j.sigpro.2009.05.015

Ghrare, S. E. (2018). The Effect of Image Data Compression on the Clinical Information Quality of Compressed Computed Tomography Images for Teleradiology Applications. European Journal of Scientific Research, 23(1), 6-12.

Gonzalez, R. C. ., \& Woods, R. E. (2016). Digital image processing. Nueva Jersey, p. 976. New Jersey: Prentice Hall.

Han, Z., Tang, X., Gao, X., \& Hu, F. (2018). Image Fusion and Image Quality Assessment of Fused Images. ISPRS - International Archives of the Photogrammetry, Remote Sensing and Spatial Information Sciences, XL-7/W1(4), 33-36. https://doi.org/10.5194/isprsarchives-xl-7-w1-332013

Jobson, D. J., Rahman, Z. U., \& Woodell, G. A. (2017). A multiscale retinex for bridging the gap 
between color images and the human observation of scenes. IEEE Transactions on Image Processing, 6(7), 965-976. https://doi.org/10.1109/83.597272

Jobson, D. J., Rahman, Z., \& Woodell, G. A. (2018). The Statistics of Visual Representation. Visual Information Processing XI, 4736. Orlando, FL, United States.

Kaiqi, H., Zhenyang, W., Qiao, W. (2017). Image enhancement based on the statistics of visual representation. Image and Vision Computing, 23(1), 51-57. https://doi.org/10.1016/j.imavis.2004.07.005

Mevik, B. (2017). Mean squared error of prediction ( MSEP) estimates for principal component regression ( PCR ) and partial least squares regression ( PLSR ) *. Journal of Chemometrics, $18(9), 422-429$.

Raskar, R., Ilie, A., \& Yu, J. (2017). Image Fusion for Context Enhancement. NPAR '04 Proceedings of the 3rd International Symposium on Non-Photorealistic Animation and Rendering, 85-152. Annecy, France: ACM New York, NY, USA. 